\title{
Bio-Enrichment of Waste Crude Oil Polluted Soil: Amended with Bacillus 139SI and Organic Waste
}

\author{
Arezoo Dadrasnia and Salmah Binti Ismail
}

\begin{abstract}
Biodegradation of waste crude oil contaminated soil amended by Bacillus 139SI and used tea leaf amendments was investigated to determine the rate of hydrocarbon remediation. Previously, Bacillus 139SI was isolated from an agricultural soil in the Serdang agricultural center, Malaysia. Within 60 days, $14 \%$ oil loss was recorded in unamended polluted autoclaved soil, while waste crude oil disappeared more rapidly in the soil amendment with both strain and organic waste, recorded above $89 \%$. Utilizing bacteria counts were significantly higher in all amended treatments comparing to control soil. Dehydrogenase activity in soil was markedly enhanced by the application of amendments. Waste crude oil composition monitored by GC/FID indicated complete degradation of $n-C_{9}-C_{25}$. First-order kinetic model revealed that organic waste and strain were the best of treatments, with biodegradation rate constant of 0.17 day $^{-1}$ and half life of 4 days. The results showed there is potential for tea leaf and Bacillus 139SI to enhance biodegradation of waste crude oil contaminated soil.
\end{abstract}

Index Terms-Bioaugmentation, biostimulation, microbial consortium, organic waste, waste crude oil.

\section{INTRODUCTION}

Modern industrial society is built and ruled by petroleum hydrocarbons. Petroleum is essential to the current global networked economy, without it, our economic order would cease to function, bringing disaster to many populations. The unintended release of hydrocarbons into the environment can negatively impact human and animal health, and change the characteristics of soils impacting the plant populations they can support [1]. Sonawdekar [2] reported that the amount of natural crude oil spill is estimated to be 600,000 metric tons per year with a range of uncertainty of 200,000 metric tons per year. The rapid transition from an agricultural economy to an industrial economy in some developing countries like Malaysia makes it probable that hydrocarbon environmental pollution is a significant issue. As long as oil is stored, used and transport, there is a potential threat of oil spillage in environment Crude oil, as a result of PAHs content, interrupts the survival, reproduction, development and growth of organisms. This may increase the risk of mortality from infectious diseases [3]. A diversity of bioremediation techniques has been developed to increase the degradation rate of contaminated sites [4], [5]. More than 200 species of bacteria, yeasts, and fungi have been identified, which are

Manuscript received April 29, 2014; revised July 9, 2014. This work was supported in part by OCAR chancellery of University Malaya with grant number A-21010-DA674 and A-21010-DA677.

The authors are with the Institute of Biological Sciences, Faculty of Science, University of Malaya, 50603 Kuala Lumpur, Malaysia (e-mail: salmah_r@um.edu.my, are.dadrasnia@gmail.com). capable of degrading hydrocarbons. In addition, many studies have proven the positive effects of biostimulation in the restoration of total petroleum hydrocarbon contaminated sites [6], [7].

The seriousness of waste crude oil pollution in our environment and the possibility of bioremediation by biostimulation and bioaugmentation are the driving force behind this study. The aim of this research was to explore the feasibility of using biosurfactant (Bacillus 139SI) and organic waste (used tea leaf) to remedy soil, which has been contaminated by waste crude oil. A series of microcosm study was conducted in a greenhouse condition for evaluation of oil-degrading microorganisms in the bioremediation process.

\section{MATERIAL AND METHOD}

\section{A. Collection of Samples}

Organic waste (tea leaf) and soil were collected from the Science Canteen and the garden section University of Malaya, respectively. Waste crude oil collected from a refinery station in Malaysia and its profile analyzed using GC. Physicochemical properties such as moisture content, $\mathrm{pH}$, total nitrogen, organic carbon and phosphorus were determined using the standard methods.

\section{B. Bacterial Culture and Inoculum Preparation}

Bacillus 139SI was originally obtained from an agricultural soil in the Serdang agricultural center, Malaysia, which reported earlier [8]. Cultivation was carried out at $37^{\circ} \mathrm{C}$ in brain-heart infusion (BHI) agar including $5 \%$ sheep blood [8]. This soil was suspended in $3 \mathrm{~mL}$ of sterile distilled water; the suspension was streaked on BHI for a period of $24 \mathrm{~h}$ at $37^{\circ} \mathrm{C}$. Colonies obtained from the plates were sub-cultured on BHI every month to maintain its survival. In order to obtain a standard inoculum, Bacillus 139SI was grown in BHI broth in an orbital shaker at $200 \mathrm{rpm}$ to yield an absorbance reading $(\mathrm{OD}=1)$ at $600 \mathrm{~nm}$. The cells were harvested in mineral salt media (MSM).

\section{Bio-Enhanced of Waste Crude Oil}

$0.5 \mathrm{~kg}$ of fresh soil was placed in the plastic poly bags labeled A to $\mathrm{H}$ and polluted with $3 \%(\mathrm{w} / \mathrm{w})$ waste crude oil. After 2 days, $5 \%$ of the tea leaf (TL) added into each of the oil polluted soil, labeled A, B and C, respectively. The soils were mixed daily to provide sufficient aeration. After 3 days of stabilization, $10 \%$ (v/w) of Bacillus 139SI. As a biosurfactant (BF) with inoculum $\times 10^{8}$ colony forming units $(\mathrm{CFU} / \mathrm{g})$ added to contaminated soil. Soil moistened by the addition of water every other day to adjust the water holding capacity to 
maintain at $60 \%$ throughout the experimental period. In addition, the control with only soil and oil and an additional control treatment, autoclaved twice (within the same day at $121{ }^{\circ} \mathrm{C}$ and 15 psi for $1 \mathrm{~h}$ ) and then $0.5 \%$ (w/w) $\mathrm{NaN}_{3}$ was added, to determine the non-biological loss of oil from the soil. All the treatments were set-up in triplicates. The contaminated soils were sampled every 10 days for a period of 60 days. Experiments were conducted with the following combinations:
A: Soil $+3 \%$ waste crude oil $+5 \% \mathrm{TL}+\mathrm{BF}$
B: Soil $+3 \%$ waste crude oil $+\mathrm{BF}$
C: Soil $+3 \%$ waste crude oil $+5 \%$ TL
D: Soil $+3 \%$ waste crude oil
E: Autoclaved Soil $+3 \%$ waste crude oil $+5 \% \mathrm{TL}+\mathrm{BF}$
F: Autoclaved Soil $+3 \%$ waste crude oil + BF
G: Autoclaved Soil $+3 \%$ waste crude oil $+5 \%$ TL
$\mathrm{H}$ : Autoclaved Soil $+3 \%$ waste crude oil

\section{Determination of Oil Content in Soil}

The concentration of oil in soils was determined gravimetrically by ultrasonic extraction. $10 \mathrm{~g}$ of soil sample placed in $250 \mathrm{ml}$ conical flask with n-hexane: acetone (ratio $1: 1$ ) for $30 \mathrm{~min}$, using an ultrasonic instrument (1210E-MTH, USA) at $25{ }^{\circ} \mathrm{C}$. After sonication, the extract was separated from the sample by centrifugation at $5000 \mathrm{rpm}$ for $5 \mathrm{~min}$. The above procedures were repeated twice and the extracts were decanted off after each extraction. Solvent was separated from the extract by distillation and drying. Percentage of degradation of oil calculated using the following formula [6]:

\section{Biodegradation $(\%)=\mathrm{TC}-\mathrm{TT} / \mathrm{TC} \times 100$}

where TPH is total petroleum hydrocarbon. TC: TPH in control, TT: TPH in treatment. The analysis of the residual hydrocarbon in the soil will determine using GC coupled to a flame ionization detector (FID). Helium carrier gas flow will be $1.27 \mathrm{ml}$ min-1. The column oven was initially held at 50 ${ }^{0} \mathrm{C}$ for $2 \mathrm{~min}$, increased to $300{ }^{0} \mathrm{C}$ at a rate of $6{ }^{0} \mathrm{C} \mathrm{min}{ }^{-1}$, then to $300{ }^{\circ} \mathrm{C}$ (held for $16 \mathrm{~min}$ ).

\section{E. Dehydrogenase Activity}

Dehydrogenase activity was determined by monitoring the rate of reduction of 2, 3, 5-triphenyltetrazolium chloride (INT) as a substrate [9].

\section{F. Kinetics of Oil Removal and Half Life}

First-order kinetics model used is expressed by the following equation [10],

$$
C_{t}=C_{i} \exp (-k t)
$$

where $C_{t}(\mathrm{mg} / \mathrm{g})$, is the oil concentration in soil at instant $t$, $C_{i}(\mathrm{mg} / \mathrm{g})$ is the initial concentration of soil, $k$ is the rate constants of the first order expressed in $\left(\right.$ day $\left.^{-1}\right)$, and $t$ is the time. The model estimated the biodegradation rate and half life of hydrocarbons in soil relative to treatments applied.

$$
\text { Half-life }=\operatorname{Ln} 2 / k
$$

To indicate the proportion of the variation explained by the model, the coefficient of multiple determinations $\left(R^{2}\right)$ was calculated;

$$
R^{2}=1-\mathrm{RSS} / \mathrm{CTSS}
$$

where RSS was the residual sum of squares, and CTSS was the corrected total sum of squares. The data will be analyzed for significant differences $(p<0.05)$ between treatments using one-way analyses of variance with SPSS 18.

\section{RESUlTS AND DisCUSSION}

The physicochemical properties of the investigated soil (Sandy loam) and biowaste used in this biodegradation study are presented in Table I. It is clear that the soil had a low $\mathrm{N}$ $(0.04 \%)$ and $\mathrm{P}(0.6 \%)$ content compared to TL. Hence, it is needed addition of organic waste as a source of nutrient. TL had the highest $\mathrm{N}$ and $\mathrm{P}$ content compare to soil used; this is one of the most important limiting nutrients for effective bioremediation [11].

TABLE I: PHYSICOCHEMICAL PROPERTIES OF SOIL AND ORGANIC WASTE USED FOR BIOREMEDIATION

\begin{tabular}{ccc}
\hline \hline Parameters & Soil & TL \\
\hline Nitrogen (\%) & 0.04 & 0.1 \\
Phosphorus (ppm) & 60 & 134 \\
Potassium (ppm) & 197 & 236 \\
Moisture content (\%) & 9.6 & 41.5 \\
Organic C (\%) & 4.25 & 5.34 \\
pH & 7.2 & 6.8 \\
Texture & Sandy loam & - \\
\hline \hline
\end{tabular}

\section{A. Biodegradation of Waste Crude Oil}

Initial of concentration of oil in the soil was $30000 \mathrm{ppm}$ of soil $(3 \% \mathrm{w} / \mathrm{w})$. Fig. 1 shows the profile of residual waste crude oil in different treatments during the period of 60 days. $3120 \mathrm{ppm}(10.4 \%)$ oil was remained in treatment A compare to $17100 \mathrm{ppm}(57 \%)$ in treatment $\mathrm{D}$. The reduction of residual hydrocarbons in the soil was observed in all the treatments. Treatments E, F, G and $\mathrm{H}$ with autoclaved soil recorded $48 \%, 46 \%, 46 \%$ and $14 \%$ biodegradation, respectively. It is approve the effect of microorganism to enhance the rate of biodegradation. Chang et al. [12] illustrated the rate of degradation was enhanced by using microbial inoculants in bioremediation process. However, other environmental factors such as $\mathrm{pH}$, temperature, nutrients and moisture are important key to influence the microbial growth and biodegradation rate which has been reported in many studies. Chang et al. [13] reported the increase rate of oil removal by using A. baumannii T30C in a period of 35 days; the soil was tilled to improve the chemical and physical properties. On the other hand, temperature also played the main role in the metabolism of microbial hydrocarbon which is attributed to the breakdown of hydrocarbon compounds. Room temperature of soil treatments was conducted was $33 \pm 2{ }^{\circ} \mathrm{C}$ over the 60 days of study in the greenhouse. Zekri and Chaalal [14] reported that increasing the temperature led to increase the rate of hydrocarbon degradation by thermophilic bacteria of Bacillus sp. Biological activity also is widely affected by 
availability of nutrients and tolerance of microorganisms to $\mathrm{pH}$ variation. The present study demonstrated that the rate of degradation in unamended control soil and autoclaved soil was 43 and 14\%, respectively, which was significantly lower than soil amended with Bacillus 139SI and TL. Similar results were obtained by Van Gestel et al. [15] who reported $85 \%$ diesel oil reduction in contaminated soil amended with different composts (vegetable, fruit and garden waste) at a ratio of 1:10 (oil/compost) over a period of 12 weeks.

Comparison of means revealed that there was a significant difference $(p<0.05)$ between the unamended soil (control) with treatments amended with BF and TL, which proves the positive effect of biosurfactant during the biodegradation of waste crude oil in the soil. The lowest rate of degradation was recorded is soil amended with TL (treatment $\mathrm{C}$ and $\mathrm{G}$ ) with $72.5 \%$ and $46 \%$, respectively compare to those treatments amended with biosurfactant (Bacillus 139SI) only (treatments B and F) with $76.2 \%$ and $46 \%$ degradation, respectively in polluted soil with crude oil. This is in contrast with results of Chang et al. [12] who reported treatments amended with nutrients only had the highest rate of degradation compare to treatments amended with bacterial isolate. The reason could due to limitation of nutrients in the soils and also might be the differences in microbial ecology of the soil used for these two experiments.

Schaefer and Juliane [16] evaluated the effect of different additives such as brewery and horticultural wastes on total petroleum hydrocarbon (TPH) degradation at $5000 \mathrm{mg} / \mathrm{Kg}$ concentration of crude oil and indicated that the application of these wastes as treatment amended did not enhance the degradation of oil. They assumed that micro-organisms preferred the additives as nutrient sources over the less easily degradable, nitrogen deficient, long-chain crude oil [16].

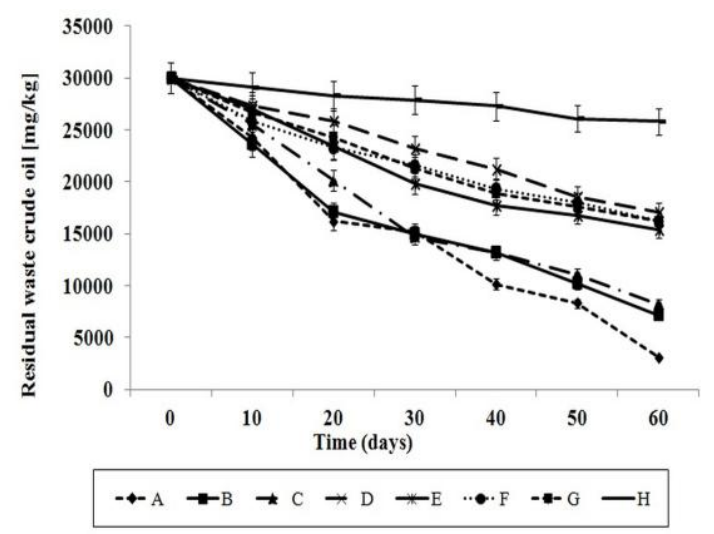

Fig. 1. Residual hydrocarbons in different treatments of waste crude oil contaminated soil.

\section{B. Dehydrogenase Activity (DHA)}

Biological oxidation activity was investigated based on DHA enzyme to evaluate the efficiency of the microbial community to utilize organic compounds (Fig. 2). DHA was significantly increased with time. The highest microbial activity was recorded by soil amended with TL and BF (310 $\mu \mathrm{INTF} / \mathrm{g} \mathrm{dw}$ ) at 60 days, which is 4.4 fold higher than unamended control soil in the same time. These results agree with the findings of Aparna et al., [17] who reported that in the biostimulation process with nutrient addition there was increased dehydrogenase activity from $5.8 \mu \mathrm{g} \mathrm{INTF/g} \mathrm{dw} \mathrm{to}$
$95.6 \mu \mathrm{g} \mathrm{INTF} / \mathrm{g} \mathrm{dw}$ in the period of 36 days. At the end of two months, DHA recorded in treatments B, C and D were 256, 121 and $60 \mu \mathrm{g}$ INTF/g dw. The result contrasts with those of Lee et al. [18] which demonstrated a significant decrease in DHA during the bioaugmentation and biostimulation process on the $23^{\text {rd }}$ day of study and increased gradually until the end of 40 days due to low water content.

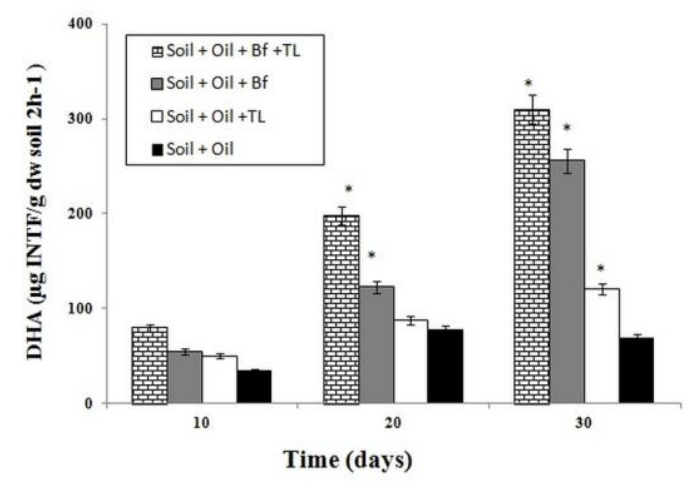

Fig. 2. Dehydrogenase activity in soil polluted.

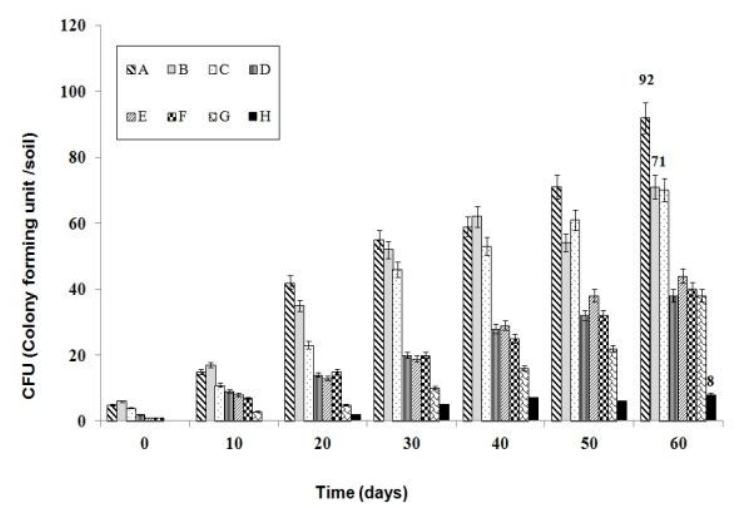

Fig. 3. Total CFU of aerobic heterotrophic bacterial (AHB) in polluted oil. Bars indicate standard error $(n=3)$.

\section{The Microbial Population of Soil Polluted with Waste Crude Oil}

No significant difference was recorded in aerobic heterotrophic bacterial (AHB) counts among polluted soils with different amendments (Fig. 3). At the end of 60 days, 92 $\times 10^{5} \mathrm{CFU} / \mathrm{g}$ of soil was recorded in treatment $\mathrm{A}$ which recorded a higher number of AHB. In treatment B refers to the amended with BF only, the number of CFU was increased until 40 days and then decreased to $54 \times 10^{5} \mathrm{CFU} / \mathrm{g}$ of soil followed by increase at 60 days to $71 \times 10^{5} \mathrm{CFU} / \mathrm{g}$ of soil. Thereby, it was approved that Bacillus 139SI was played an important role in the reduction of residual hydrocarbon. The result agreed with Padayachee and Lin [19] who reported an increase in bacterial population from $2.0 \times 10^{6}$ to $3.2 \times 10^{6}$ $\mathrm{CFU} / \mathrm{ml}$ in soil polluted with diesel oil during the $1^{\text {st }}$ week of all supplemented microcosms amended with fertilizers. This was supported by the results of treatment B in which only bacteria isolated was augmented without the addition of nutrients. However, results indicate that autoclaved soils amended shows lower counts than those treatments with normal soil. In treatments $\mathrm{C}$, the rate of degradation was $72.5 \%$, which was approximately $21750 \mathrm{mg} / \mathrm{kg}$ reduction in residual oil; however, the cell count increased from $4 \times 10^{5}$ to $7 \times 10^{6} \mathrm{CFU} / \mathrm{g}$ of soil. The difference in the microbial population in other studies compared with this study might be 
due to the different type of oil and the microbial ecology of the soil which was used in those studies. This finding is similar to Bento et al. [20] who recorded a higher count of AHB in soil polluted with diesel fuel and amended with crop residues.

\section{Kinetics Model and Half-Life of Biodegradation}

Table II shows the biodegradations constant rate in the different treatments. Half-life indicates the length of time it takes to degrade half of the hydrocarbon. The coefficient of determination $\left(\mathrm{R}^{2}\right)$ indicates that the model fits well with all the treatments. The kinetics parameter shows the highest rate of degradation in soil polluted with $3 \%$ waste crude oil accrued in soil amended with Bacillus 139SI and TL $(k=$ $0.17 /$ day and half-life of 4 days). It illustrates that the combination of the TL and biosurfactant is the most effective treatment in stimulating the degradation of soil polluted with waste crude oil throughout the study period. While, the lowest rate of degradation was recorded in unamended control autoclaved soil with 0.04/day. The reason which could be attributed to the reduction of the population of microorganism and enzyme activity in different oil polluted soil. In addition, the reason for the higher rate of biodegradation in soil amended with TL might be the buffering effects of TL and bacterial inoculation and presenting higher quantities of $\mathrm{N}$ and $\mathrm{P}$ compared to control treatments which attributed to its $\mathrm{C}: \mathrm{N}$ ratio. The result is similar to that of Medjor et al. [21] who reported that at the end of 1200 hours of bioremediation of groundwater polluted with diesel oil, first order reaction showed the constant rate of 0.002 hour-1and half-life $(t 1 / 2)$ of 346.5 hours. Dadrasnia and Agamuthu [7] also have indicated that soil treated with soycake (SC) with a higher amount of $\mathrm{N}$ and $\mathrm{P}$ recorded a high biodegradation rate at the end of three months of study. They reported low half-life and high biodegradation rate constant in diesel contaminated soil with biowastes amendment compared with unamended control soil.

TABLE II: KinETIC MODEL, AND HALF-LifE OF WASTE CRUdE OIL DEGRADATION

\begin{tabular}{cccc}
\hline \hline Treatment & $\begin{array}{l}\text { Biodegradation } \\
\text { constant }(k) \\
\text { day-1 }\end{array}$ & $\begin{array}{c}\text { Half- life } \\
\text { (days) }\end{array}$ & $R^{2}$ \\
\hline A & 0.173 & 4 & 0.95 \\
B & 0.140 & 5 & 0.87 \\
C & 0.120 & 5.8 & 0.93 \\
D & 0.052 & 13.3 & 0.94 \\
E & 0.107 & 6.5 & 0.81 \\
F & 0.091 & 7.6 & 0.92 \\
G & 0.082 & 8.4 & 0.80 \\
H & 0.040 & 17.3 & 0.93 \\
\hline \hline
\end{tabular}

* Shows significant difference at the $p<0.05$ level.

Representatives of GC/MS chromatograms showing the total petroleum hydrocarbon patterns at 0 day and at the end of $60^{\text {th }}$ days of treatment amended with TL and biosurfactant is illustrated in Fig. 4. Comparison of the chromatograms before and after the biodegradation process demonstrated that the most hydrocarbon fractions had been removed at the end of study compared with unamneded controlled soil. At the end of study, the hydrocarbon fraction in the range of $\mathrm{C}_{19}$ to $\mathrm{C}_{25}$ in soil higher degradation compared with the start of the experiment. These results agree with $\mathrm{Xu}$ and $\mathrm{Lu}$ [22] who reported the removal of $\mathrm{C}_{12}$ to $\mathrm{C}_{29}$ compounds from crude oil polluted soil, at the end of the incubation period. Nevertheless, in this study result of GC revealed the most of the aliphatic hydrocarbons extracted from polluted soil have been utilized by Bacillus 139SI together with indigenous microorganisms.

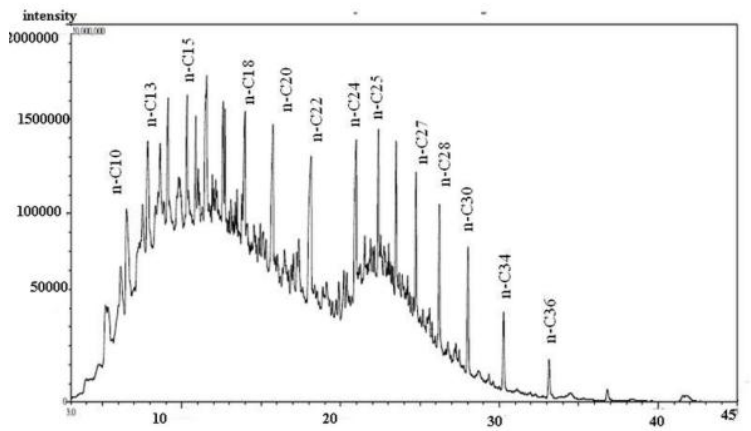

(a)

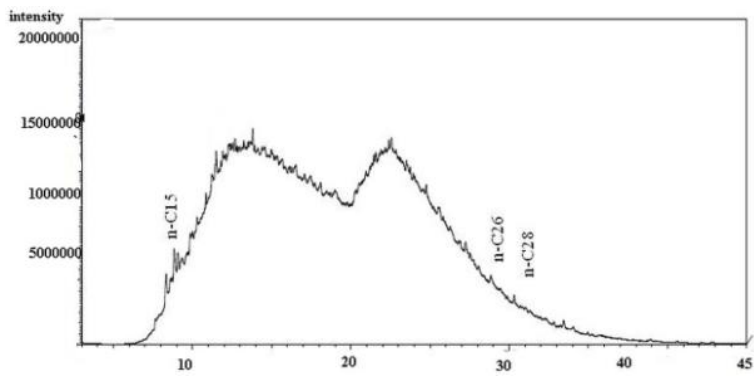

(b)

Fig. 4. Chromatogram of residual crude oil in contaminated soil amended with TL and Bacillus 139SI. a) GC profile at 0 day, b) GC profile at 60 days

\section{CONCLUSION}

The mixture of Bacillus 139SI and waste tea leaf enhanced the degradation efficiency of waste crude oil contaminated soil. Indeed, multifunction of bio surfactants is known with different chemical structures and surface properties which have important roles in the uptake and mechanisms of mineralization in hydrocarbon polluted soil. However, biosurfactant shows high potential to remediate of hydrocarbons from contaminated soil.

\section{ACKNOWLEDGMENT}

Authors wish to express their deepest thank to University of Malaya for providing the research grant to fund this research. The authors would like to thank all lab members in Molecular Biotechnology and Toxicology laboratory for their assistance.

\section{REFERENCES}

[1] R. Yu, "Bioremediation of Polycyclic Aromatic Hydrocarbon (PAH)Contaminated soils in a roller baffled bioreactor," M.Sc thesis, University of Saskatchewan, Saskatoon, Saskatchewan, pp. 1-149, 2006.

[2] S. Sonawdekar, "Bioremediation: A boon to hydrocarbon degradation," International Journal of Environmental Sciences, vol. 2, pp. 2408-2423, 2012.

[3] I. N. E. Onwurah, V. N. Ogugua, N. B. Onyike, A. E. Ochonogor, and O. F. Otitoju, "Crude oil spills in the environment, effects and some innovative clean-up biotechnologies," International Journal of Environmental Research, vol. 1, pp. 307-320, 2007.

[4] J. C. Tang, X. W. Niu, Q. Sun, and R. G. Wang, "Bioremediation of petroleum polluted soil by combination of rye grass with effective 
microorganisms," in Proc. the International Conference on Environmental Science and Information Application Technology, Tianjin, China, 2009, vol. 2, pp. 51-54.

[5] A. Dadrasnia and P. Agamuthu, "Dynamics of diesel fuel degradation in contaminated soil using organic wastes," International Journal of Environmental Science and Technology, vol. 10, pp. 769-778, 2013.

[6] O. P. Abioye, P. Agamuthu, and A. R. Aziz, "Biodegradation of used motor oil in soil using organic waste amendments," Biotechnology Research International, vol. 2012, pp. 1-8, 2012.

[7] A. Dadrasnia and P. Agamuthu, "Diesel fuel degradation from contaminated soil by Dracaena reflexa using organic waste supplementation," International Journal of the Japan Petroleum Institute, vol. 56, pp. 236-243, 2013.

[8] I. Salmah, C. T. Teow, Y. U. Choong, M. A. Saad, and O. Rahmat, "Paenibacillus hemolyticus, the first hemolytic Paenibacillus with growth-promoting activities discovered," Biologia, vol. 67, no. 6, pp. 1031-1037, 2012.

[9] M. Rosa and S. Franz, Manual of Soil Analysis-Monitoring and Assessing Soil Bioremediation Soil Biology, 1st ed. Springer, 2005, vol. 5, pp. 309-320.

[10] W. Chu and K. H. Chan, "The mechanism of the surfactant-aided soil washing system for hydrophobic and partial hydrophobic organics,' The Science of the Total Environment, vol. 307, pp. 83-92, 2003.

[11] A. I. Okoh, "Biodegradation alternative in the cleanup of petroleum hydrocarbon pollutants," Biotechnology and Molecular Review, vol. 1, pp. 38-50, 2006.

[12] W. Chang, M. Dyen, L. Spagnuolo, P. Simon, L. Whyte, and S. Ghoshal, "Biodegradation of semi- and non-volatile petroleum hydrocarbons in aged, contaminated soils from a sub-Arctic site: laboratory pilot-scale experiments at site temperatures," Chemospher, vol. 80, pp. 319-326, 2010

[13] L. K. Chang, D. Ibrahim, and I. C. Omar, "A laboratory scale bioremediation of Tapis crude oil contaminated soil by bioaugmentation of Acinetobacter baumannii T30C," African Journal of Microbiology Research, vol. 5, pp. 2609-2615, 2011.

[14] A. Y. Zekri and O. Chaalal, "Effect of temperature on biodegradation of crude oil," Energy Sources Part A, vol. 27, pp. 233-244, 2005.

[15] K. Van Gestel, J. Mergaert, J. Swings, J. Coosemans, and J. Ryckeboer, "Bioremediation of diesel oil-contaminated soil by composting with biowaste," Environmental Pollution, vol. 125, pp. 361-368, 2003.

[16] M. Schaefer and F. Juliane, "The influence of earthworms and organic additives on the biodegradation of oil contaminated soil," Applied Soil Ecology, vol. 36, pp. 53-62, 2007.

[17] C. Aparna, P. Saritha, and V. Himabindu, "Evaluation of bioremediation effectiveness on sediments Contaminated with industrial wastes," International Journal of Environmental Sciences, vol. 1, pp. 607-620, 2010.

[18] E.-H. Lee, Y.-S. Kang, and K.-S. Cho, "Bioremediation of diesel-contaminated soils by natural attenuation, biostimulation and bioaugmentation employing Rhodococcus sp EH83," Korean Journal of Microbiology and Biotechnology, vol. 39, pp. 86-92, 2011.
[19] D. Padayachee and J. Lin, "The effect of fertilizer amendment on diesel biodegradation in contaminated soils," African Journal of Microbiology Research, vol. 5, pp. 1729-1739, 2011.

[20] F. M. Bento, F. A. O. Camargo, B. T. C. Okeke, and W. T. Frankenberger, "Comparative bioremediation of soils contaminated with diesel oil by naturalattenuation, biostimulation and bioaugmentation," Bioresource Technology, vol. 96, pp. 1049-1055, 2005.

[21] O. W. Medjor, F. Egharevba, O. V. Akpoveta, O. K. Ize-lyamu, and E. O. Jatto, "Kinetic Studies of Bioremediation of Hydrocarbon Contaminated Groundwater," Research Journal of Chemical Sciences, vol. 2, pp. 38-44, 2012

[22] Y. Xu and M. Lu, "Bioremediation of crude oil-contaminated soil: Comparison of different biostimulation and bioaugmentation treatments," Journal of Hazardous Materials, vol. 183, pp. 395-401, 2010 .

Arezoo Dadrasnia was born in Iran in April 1982. She received her B.Sc and M.Sc degrees in soil sciences (chemistry and fertilizer) from Iran in 2004 and 2007, respectively and Ph.D degree in environmental biotechnology / pollution from University of Malaya, Malaysia in 2013.

Currently, she is a research assistant of associate professor Salmah Binti Ismail in Molecular Bacteriology and Toxicology Laboratory, Institute of Biological Sciences, Faculty of science, University of Malaya. Her areas of research interests are remediation of soil and water, solid waste management, microbial degradation, leachate treatment, enhanced oil recovery, environmental pollution treatment and hazardous waste management researches.

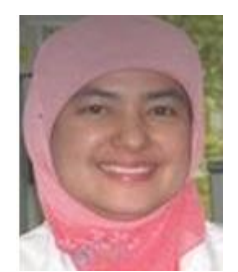

Salmah Binti Ismail was born in Kuala Lumpur, Malaysia in November 1964. She graduated from University of Malaya, Malaysia with a B.Sc. degree(Hons) in microbiology, followed by MSc. degree in bacteriology and Ph.D. degree in molecular bacteriology from same university. She is currently a lecturer in the the Biohealth Department, Institute of Biological Sciences, Faculty of Science, and University of Malaya, Malaysia. Her research interests include application of biofertilizer, plant growth promoting bacteria, biosufactant, biocontrol of agricultural diseases and pests, vaccine production for Mycobacterium tuberculosis and Plasturella multocida, wound healing, and molecular bacteriology. 